\title{
Методика визначення часу проведення технічного обслуговування зразків військової автомобільної техніки при діючий системі експлуатації
}

\author{
Павлов Денис * 1 А \\ А Національний університет оборони України імені Івана Черняховського, пр-кт Повітрофлотський 28, м. Київ, 03049, Україна
}

Received: July 20, 2021 | Revised: August 20, 2021 | Accepted: August 31, 2021

DOI: $10.33445 /$ sds.2021.11.4.10

\begin{abstract}
Анотація
У статті запропоновано варіант методики визначення часу проведення технічного обслуговування виробів військової автомобільної техніки, які перебувають в експлуатації, в міжремонтний період. Було розглянуто та проведення комплекс робіт, що дає змогу безпосереднє визначення термінів проведення технічного обслуговування в період міжремонтного терміну виробів військової автомобільної техніки, які викликають складнощі, що пов'язані, перш за все, з необхідністю оцінки впливу технічного обслуговування на параметр потоку відмов та прогнозуванні його змінення, методів яких недостатньо розроблені. Проведено аналіз існуючого методичного апарату вирішення завдань обгрунтування вимог до ефективності проведення технічного обслуговування.
\end{abstract}

Ключові слова: експлуатація, надійність, працездатність виробів, відмова, технічне обслуговування.

\section{Постановка проблеми}

Важливу роль у підтриманні необхідного рівня надійності військової автомобільної техніки (ВАТ) в боєздатному стані відіграє система технічного обслуговування (ТО) та ремонту. Розвиток технології ремонту та ТО АО безпосередньо пов'язаний з розвитком його конструкції та виробництва. Під технічним обслуговуванням виробів військового призначення розуміють комплекс операцій або операцію підтримання справності чи працездатності виробів військового призначення під час їх експлуатації [5].

Одним із видів шляхів забезпечення необхідного рівня надійності ВАT $\epsilon$ визначення відповідності змісту системи ТО процесу зміни технічного стану цієї техніки, тобто проведення ТО за реальним станом. Отже, обґрунтування можливостей переходу на систему ТО ВАT за станом, $€$ важливим науковим завданням, вирішення якого сприяє удосконаленню системи ТО й підвищенню рівня технічного стану виробів BAT, що на даний час визначає актуальність піднятої проблеми.

Найбільше значення для ефективності ТО має вирішення питання про час та об'єм робіт щодо попереджувальних замін деталей та складальних одиниць виробу (оновлення виробів озброєння) [6].

Протягом міжремонтного терміну виробів ВАТ спостерігаються два характерні періоди: початковий період (період нормальної експлуатації) та період старіння.

Початковий період характеризується, переважно, раптовими відмовами. Його тривалість, як показують дослідження [7], незначно перевищують перший міжремонтний термін. Потім починається період старіння, коли все більшого значення набувають відмови зношування та відмови, викликані незворотними процесами

\footnotetext{
1 * Corresponding author: ад'юнкт, e-mail: pavlovdenis81@ukr.net, ORCID:0000-0003-3348-7655
} 
змінення якостей матеріалів виробу. Крім тривалості та причин виникнення відмов ці періоди характеризуються таким різним значенням параметра потоку відмов, що має найбільше значення в період старіння. За таких умов проведення ТО з постійною періодичністю при заданому об'ємі не забезпечить своєчасне виявлення виниклих несправностей, тому необхідно змінювати періодичність обслуговування.

\section{Аналіз останніх досліджень та публікацій}

Дослідженню питань технічного обслуговування військової автомобільної техніки присвячений цілий ряд робіт, зокрема в роботі [1] розкриває плановопопереджувальну систему технічного обслуговування але не повністю забезпечує працездатність на високому рівні. В роботі [2] розкриває метод підтримання технічного стану військової автомобільної техніки на належному рівні, але не розкриває факторів які впливають на технічний стан.

Головним якістю машин, що застосовуються за призначенням визначено технічний стан автомобіля. Визначено, що технічний стан автомобіля являє підвищення надійності максимально повний облік особливостей і умов експлуатації. В роботі [3] розглядаються проблемні організаційні та науково-методичні питання з експлуатації та ремонту за технічним станом зенітного ракетного озброєння Повітряних Сил Збройних Сил України в умовах України. Розглядаються основні організаційні заходи переведення та експлуатації за технічним станом зенітного ракетного озброєння на наступних етапах: підготовчий, освоєння контрольно-відновлювальних робіт (КВР) на зразках установочної партії, серійного переведення на експлуатацію за технічним станом, але не розкриває повноти викладеного матеріалу щодо проведення технічного обслуговування в польових умовах. В роботі [4] Розглядаються різновиди стратегій технічного обслуговування i ремонту за технічним станом та наведена характеристика і область можливого застосування їх у практиці Збройних Сил України але значна мінімальна кількість процесів щодо проведення технічного обслуговування.

\section{Постановка завдання}

Таким чином метою статті $\epsilon$ рішення задачі щодо визначення термінів проведення технічного обслуговування в період міжремонтного терміну виробу військової автомобільної техніки 3 урахуванням характеру змінення параметра потоку відмов.

\section{Виклад основного матеріалу}

Перед тим, як перейти до опису послідовності розрахунків при обґрунтуванні структури міжремонтного терміну, коротко розглянемо склад необхідної вихідної інформації та методи її отримання.

Для практичного використання отриманих результатів необхідна така інформація:

$$
\text { дані про структуру першого }
$$
міжремонтного терміну (види ТО, терміни їх проведення та чергування);

аналітичні вирази функції потоку відмов $\omega_{H}(t)$ та функції розподілення моментів переростання несправностей у відмови $F(t)$; тривалість міжремонтного терміну.

Для визначення аналітичного виду функції $\omega_{H}(t)$ можна скористатися методикою вибору апроксимуємої функції, викладеної, наприклад в [8].

Проведені дослідження показали, що параметр потоку несправностей, які поступово переростають у відмови, може бути апроксимований залежністю виду $\omega_{н}(t)=a+m t \quad(m=28)$. Для визначення коефіцієнтів $a$ та $m$ можна використовувати метод найменших квадратів [5]. Звернемо увагу на те, що вид апроксимуємої залежності 
був отриманий на основі аналізу даних про несправності за деякий період експлуатації (міжремонтний термін) виробів. Якщо така інформація відсутня, що характерно для виробів ВАТ, які розробляються, то необхідно використовувати інформацію, що отримується зі сфери експлуатації об'єктіваналогів, або скористатися достатньо відомими методами імітаційного моделювання.

Приведені співвідношення для знаходження поправок $\tau_{k}$ були отримані за припущення довільного виду функції $F(t)$. Для практичних розрахунків можна використовувати припущення про експоненціальне розподілення часу переходу несправності у відмови, оскільки кінцевий результат буде не дуже відрізнятися від результатів, отриманих для істинного закону розподілення функції $F(t)$. Оцінка параметру розподілення $\mu$ може бути проведена відповідно до [8].

Крім перерахованих вихідних даних, для рішення практичних завдань необхідно знати величину $\Delta \mathrm{a}=\mathrm{a}_{i+1}-a_{i}$, яка характеризує ступінь відновлення початкових якостей виробу в процесі ТО. Величину $\Delta$ а можна визначити експериментально або моделюючи процеси ТО та експлуатації.

3 урахуванням викладених міркувань за необхідною вихідною інформацією сформулюємо основні положення обґрунтування структури міжремонтного терміну.

1. Визначається аналітичний вид функції $\omega_{\mathrm{H}}(t)$ та $F(t)$.

2. Перевіряється наявність тенденції до збільшення функції $\omega_{H}(t)$. Якщо тенденція до збільшення функції $\omega_{H}(t)$ відсутня, то розподілення моментів проведення ТО слід вважати регулярним, тобто $T_{\text {TO- } i}=$ const.

3. За характером функції $\omega_{H}(t)$ та $F(t)$ вибираються відповідні розрахункові співвідношення, що надані в підпрограмі вибору критерію приєднання робіт (рис. 1), та проводиться вирахування поправок $\tau_{k}$ до моментів проведення ТО найбільшого обсягу $T$, визначеного за припущення $\omega_{\mathrm{H}}(t)=$ const.

4. Визначаються значення $T_{\text {Цто }}^{(k)}\left(T_{\text {цто }}^{(k)}\right.$ тривалість $k$-го міжремонтного терміну, $k=$ $1,2,3,4)$

$$
T_{u_{T O}}^{(k)}=k T+\tau_{k} .
$$

5. Визначаються періодичності проведення ТО менших обсягів:

$$
t_{T O-j}=\frac{T_{u T O}^{(k)}}{n j},
$$

де $n_{j}-$ число ТО $j$-го виду на першому міжремонтному терміні; $T_{u_{T O}}^{(k)}-$ тривалість $k$ го міжремонтного терміну.

Відповідно до заданої методики була розроблена модель для розрахунків під час обґрунтування міжремонтного терміну ВАТ. Алгоритм даної моделі показаний на рис 1.

Відповідно до запропонованої методики була обґрунтована структура міжремонтного терміну ВАТ (КАМАЗ-5410). Результати розрахунків приведені в табл. 1. Як видно 3 наведеної таблиці структура міжремонтного терміну, яка розроблена відповідно до запропонованої методики, відрізняється від структури міжремонтного терміну, що встановлений діючою системою ТО, передусім термінами проведення обслуговувань на різних ТО.

Періодичність обслуговування на першому TO 3 перемінним циклом обслуговування відрізняється від існуючого. Однак слід мати на увазі, що в реальній експлуатації також має місце незначний відступ термінів проведення ТО, встановлених директивно, у бік збільшення, в силу ряду об'єктивних причин, наприклад, завантаженості ремонтних органів. I при цьому збільшення параметра потоку відмов або інших небажаних наслідків не спостерігається. Періодичність видів ТО на другому циклі обслуговування приблизно однакова. 


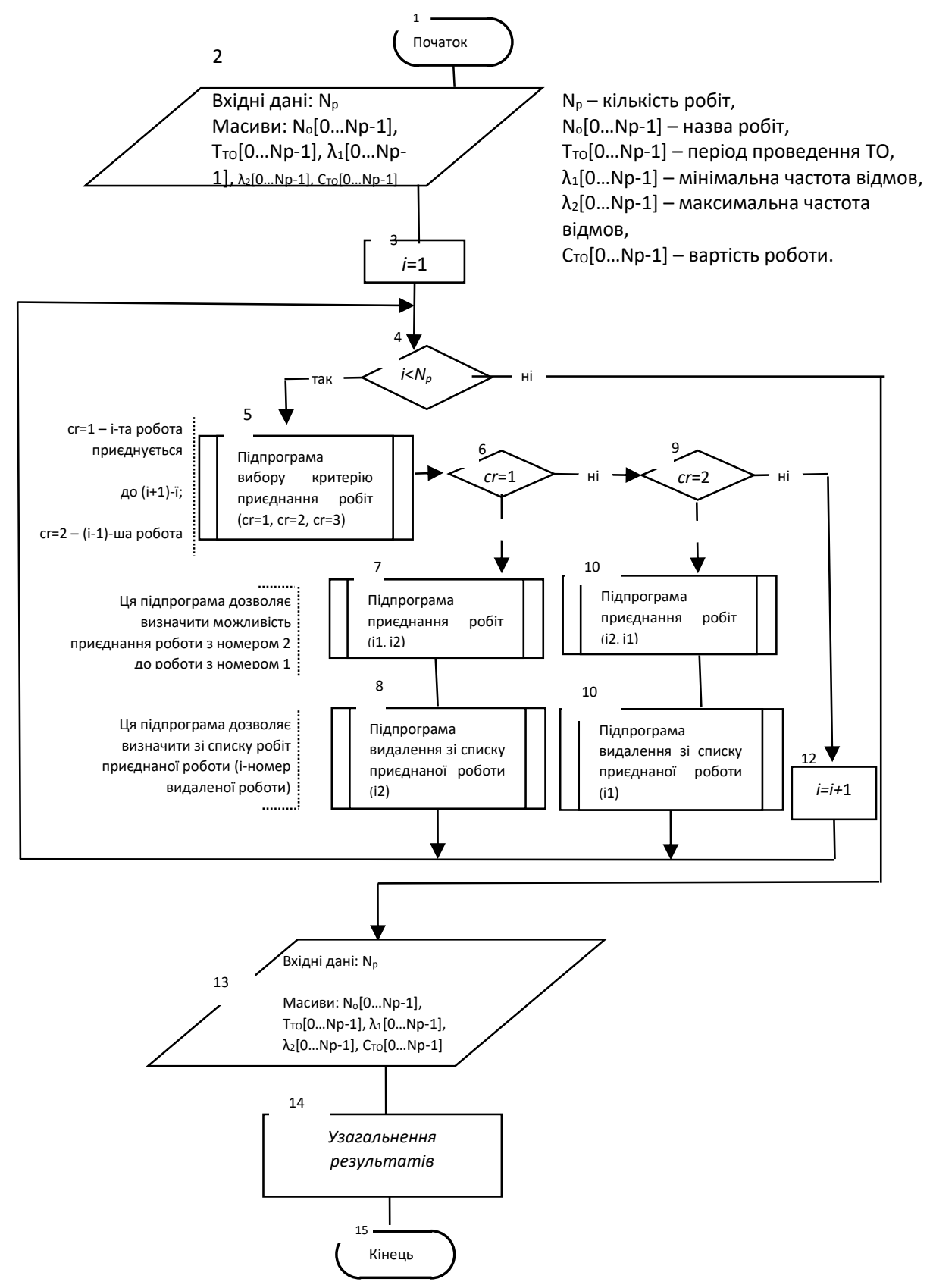

Рисунок 1 - Блок-схема алгоритму методу групування робіт по ТО

Таблиця 1 - Структура міжремонтного терміну

\begin{tabular}{|c|c|c|c|}
\hline & Перше ТО & Друге ТО & Третє ТО \\
\hline $\begin{array}{c}\text { Поправки } \tau_{k} \text { до } \\
\text { моментів проведення ТО }\end{array}$ & $\tau_{1}=0,5$ року & $\tau_{2}=1,75$ року & $\tau_{3}=1$ рік \\
\hline Значення $T_{\psi_{T O}^{(k)}}^{(k)}$ & $T_{\text {}_{T O}^{(1)}}=1,5$ року & $T_{u_{T O}^{(2)}}^{(2)}=3,25$ року & $T_{u_{T O}^{(3)}}=4,25$ року \\
\hline Періодичність $t_{T O-j}$ & $t_{T O-1}=4,5$ місяця & $t_{T O-2}=5,6$ місяця & $t_{T O-3}=8,5$ місяця \\
\hline
\end{tabular}

На третьому циклі періодичність окремих видів ТО, визначених відповідно до розробленої

$$
\text { методики, }
$$

періодичність видів ТО, які встановлені діючою системою ТО. 


\section{Висновки}

Таким чином, отримані результати прямо протилежні наміченій тенденції - скорочення трудомісткості обслуговування шляхом збільшення періодичності. Число видів ТО для обох випадків, які тут розглядаються, однакове. Відповідно, в першому наближенні витрати на проведення ТО також можна вважати однаковими. Тому оцінити доцільність зменшення тривалості ТО можна лише на основі кількісної оцінки впливу ТО на стан виробу. Іншими словами, слід оцінити ефективність розробленого варіанту системи ТО та на основі цієї оцінки прийняти рішення про доцільність вибору розробленого варіанту в якості базового.

\section{Список використаних джерел}

1. Кривцун В. І., Наканевский В. Й., Баранов А. М. Порівняльний аналіз існуючих систем технічного обслуговування і ремонту машин. Академія сухопутних військ ім. гетьмана Петра Сагайдачного, вісник машинобудування та транспортування №1, 2015 року.

2. Баранов А. М., Баранов Ю. В., Іванський В. О. Аналіз факторів, які впливають на ефективність функціонування системи технічного обслуговування і ремонту. Збірник наукових праць академії Державної прикордонної служби України "Військові технічні науки" том 81, №3, (2019).

3. Гриб Д. А., Ланецький Б. М. Експлуатація та ремонт за технічним станом озброєння і військової техніки зенітних ракетних військ проблемні питання та шляхи їх вирішення. Харківський Національний університет Повітряних Сил ім. Івана Кожедуба. Видання системи озброєння і військова техніка, 42, №2, (2015)

\section{Методика определения времени проведения технического обслуживания образцов военной автомобильной техники при действующий системе эксплуатации}

\author{
Денис Павлов * 1 А
}

Corresponding author:*1 адъюнкт, e-mail: pavlovdenis81@ukr.net, ORCID:0000-0003-3348-7655

А Национальный университет обороны Украины имени Ивана Черняховского, пр-кт Воздухофлотский, 28, г. Киев, 03049, Украина
4. Чорний Н. В., Долгов Р. В., Стратегії технічного обслуговування і ремонту озброєння та військова техніка. Збірник академія сухопутних військ ім. гетьмана Петра Сагайдачного, експлуатація та відновлення озброєння та військова техніка, №1, (2009).

5. ДСТУ В 3576-97 Експлуатація та ремонт військової техніки. Терміни та визначення - К.: Держстандарт України. 2008.

6. Салуквадзе К. В. Теоретические основы експлуатации артилерийского вооружения / Салуквадзе К. В. Староселец В. Г., Чухнин В. Н. - М., Воениздат, 1985. - 415 с.

7. Мартищенко Л.А. и др. Военно-научные исследования и разработка вооружения и военной техники. Часть ІІ. - Л. ВАА, 1993. $555 \mathrm{c}$.

8. Вентцель Е. С. Теория вероятностей / Вентцель Е. С., Овчаров Л. А. - М., Наука, 1973. -343 c.

\footnotetext{
Аннотация

В статье предложено вариант методики определения времени проведения технического обслуживания изделий военной автомобильной техники, которые находятся в эксплуатации, в межремонтный период. Были рассмотрены и проведения комплекс работ, что дает нам непосредственное определение сроков проведения технического
} 
обслуживания в период межремонтного срока изделий военной автомобильной техники которые вызывают сложности, связанные, прежде всего, с необходимостью оценки влияния технического обслуживания на параметр потока отказов и прогнозировании его изменение, методов которых недостаточно разработаны. Проведен анализ существующего методического аппарата решения задач обоснования требований к эффективности проведения технического обслуживания.

Ключевые слова: эксплуатация, надежность, работоспособность изделий, отказ, техническое обслуживание.

\title{
Methods for determining the time of maintenance of samples of military vehicles with the current system of operation
}

\author{
Denis Pavlov * 1 A \\ Corresponding author: *1PhD student, e-mail: pavlovdenis81@ukr.net, ORCID:0000-0003-3348-7655

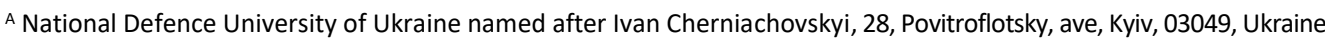

\begin{abstract}
The article proposes a variant of the method of determining the time of maintenance of military vehicles, which are in operation, in the repair period. A set of works was considered and carried out, which allows us to directly determine the timing of maintenance during the service life of military vehicles, which cause difficulties associated primarily with the need to assess the impact of maintenance on the parameter of the flow of failures and predict it changes, the methods of which are insufficiently developed. The analysis of the existing methodical apparatus of the decision of problems of substantiation of requirements to efficiency of carrying out maintenance is carried out.
\end{abstract}

Keywords: operation, reliability, serviceability of products, failure, maintenance.

\section{References}

1. Krivtsun V.I., Nakanevsky V.Y., Baranov A.M. Comparative analysis of existing systems for maintenance and repair of machines. Academy of Land Forces. Hetman Petro Sagaidachny, Bulletin of Mechanical Engineering and Transportation. №1, 2015.

2. Baranov A.M., Baranov Y.V., Ivansky V.O. (2019) Analysis of factors that affect the efficiency of the maintenance and repair system. Collection of scientific works of the Academy of the State Border Guard Service of Ukraine "Military Technical Sciences". vol. 81, №3.

3. Mushroom D.A., Lanetsky B.M. (2015) Operation and repair according to the technical condition of armaments and military equipment of anti-aircraft missile forces are problematic issues and ways to solve them. Kharkiv National University of the Air Force. Ivan Kozhedub. Publication of the armament system and military equipment, 42, №2

4. Black N.V., Dolgov R.V. (2009) Strategies for maintenance and repair of weapons and military equipment. Collection of the Academy of Land Forces. Hetman Peter Sagaidachny, operation and restoration of armaments and military equipment. №1

5. DSTU B 3576-97 Operation and repair of military equipment. Terms and definitions Kyiv. State Standard of Ukraine. 2008.

6. Salukvadze K.V. Theoretical bases of operation of artillery armament / Salukvadze K. V. Staroselets V. G., Chukhnin V. N. Moscow. Voenizdat, 1985. 415 p.

7. Martishchenko L. A. etc. Military research and development of weapons and military equipment. Part II. L. VAA, 1993. 555 p.

8. Wentzel ES Probability theory / Ventzel ES, Ovcharov L.A. Moscow. Nauka, 1973. 343 p. 